\title{
A Case Study On Vulnerability Of Changing Business Environment At Cochin Port Trust
}

\author{
${ }^{1}$ Muhammed Salih. K, ${ }^{2}$ Dr. Binu C Yeldhose \\ ${ }^{1} P G$ Scholar, ${ }^{2}$ Professor, Department Of Mechanical Engineering, Mar Athanasius College of Engineering, \\ Kothamangalam, Kerala, India - 686666.
}

\begin{abstract}
This paper tries to study the present situation of Cochin Port Trust which is one of the major ports in India. The study identifies the poor capability of Cochin Port Trust to respond effectively to change in a business opportunity. This port contributed a lot towards the development of the country and the Kerala state and the state looking forwards the port trust for further development of the state.

The detailed study on the various departments of Cochin Port Trust it was identified that the present situation is not favorable for any organization especially the industries which can contribute towards the economic development of the country. The policies of the Central government and the inefficiency in the management created a situation that port is running at a net loss of 86 crores. The present management structure of Cochin Port Trusts will not be able to make a positive change in working atmosphere, Effective utilization of natural resources, and thereby contributing to the issue of unemployment in the country. So the industrials training report proposing a change in organizational structure of Cochin Port Trust. For the further development of the port it is very important that the employees of the Cochin port should come forward and should offer their maximum effort, which they are not doing at the present situation.

After a detailed study on Dry dock workshop of Cochin Port trust it is identified that this department can contribute to the revenue of Cochin Port Trust. Presence of ICTT Vallarpadam, the Central Government is planning waive the cabotage rule for ICTT Vallarpadam, the proposed Vihinjam Port is the some open opportunity in front of the port trust. This offers a scope of ship repairing hub in Cochin Port Trust with business collaboration with Cochin Shipyard.
\end{abstract}

Keywords: Cabotage rule, Cause and effect diagram, Pareto chart, ICTT Vallarpadam

\section{Introduction}

This paper tries to study the present situation of Cochin Port Trust which is one of the major ports in India .The paper studies the capability of Cochin Port Trust [1] to respond effectively to change in a business opportunity. This port contributed a lot towards the development of the country and the Kerala state and the state looking forwards the port trust for further development of the state .The development of the International Container transshipment terminal at Cochin, LNG Re gasification terminal at Cochin are the two main projects [3] which are capable to contribute a lot towards the economic development of the state Kerala and India.

In the 11th five year plan country expected a GDP growth of $8.33 \%$ but able to achieve only $7.94 \%$ [2].By considering the factor of global recession and unemployment all-around the world the country has to give a good attention to reduce unemployment in India

According to the planning commission of India to sustain the GDP growth of India it is very important that the country has to take necessary steps to monitor, invest money into the infrastructure development of the country in the following areas like Electricity, Roads and Bridged, Ports, Telecom, Irrigation etc.

\section{Literature Review}

India's rise in recent years is a most prominent development in the world economy. India has reemerged as one of the fastest growing economies in the world. India's growth, particularly in manufacturing and services, has boosted the sentiments, both within the country and abroad. According to many commentators, India could unleash its full potential, provided it improves the infrastructure facilities, which are at present not sufficient to meet the growing demand of the economy. Failing to improve the country's infrastructure will slow down India's growth process. Therefore, Indian government's first priority is rising to the challenge of maintaining and managing high growth through investment in infrastructure sector, among others. By examining text materials related to shipping in this section, we will look into the viewpoint of shipping economists about the development stages of the shipping industry [2]. The transport system in India comprises a number of distinct modes and services, notably railways, roads, road transport, ports, inland water transport, coastal shipping, airports, and airlines. Railways and roads are the dominant means of transport carrying more than 95\% of total traffic generated in the country. Although other modes such as coastal shipping and inland water 
transport would play a greater role, the railways and roads would continue to dominate the transport landscape in the foreseeable future [2].

The recent accelerated growth in Indian economy and trade underscores the increasing criticality of the shipping sector in India, as the bulk of the countries Export-Import trade takes place through the maritime route. One of the objectives of the Foreign Trade Policy 2004-09 is 'to double our percentage share of global merchandise trade within the next five years' taking it to $1.5 \%$. With 8.42 million gross tonnages (GT), India stands at the 20th rank among maritime nations, in terms of fleet size, with a share of $1.19 \%$ of the world fleet [2]. Indian tonnage was practically stagnant till 2004-05, but reforms introduced in that year stimulated a burst of growth in 2005-06. The Shipping Corporation of India (SCI), a PSU under the Department of Shipping, has a major share in India's shipping tonnage. A feature of recent experience in India's shipping sector is the sharp decline in the share of Indian ships in the carriage of India's overseas trade from 31.5\% in 1999-2000 to 13.7\% in 2004-05. The Indian shipping fleet is characterized by the predominance of oil tankers and bulk carriers. While oil tankers account for $60.6 \%$ of the total tonnage, bulk carriers account for $29.6 \%$ [2]. During the Tenth Plan, shipping tonnage witnessed a rise from 560 vessels carrying 6.82 million GT to 787 vessels amounting to 8.60 million GT. A total of 227 vessels of 1.78 million GT was added to the fleet as against a target of 156 vessels of 3.26 million GT.

India has positioned herself as a major human resource-supplying nation to the maritime industry. As a result of the initiatives taken by the government in encouraging private participation in maritime training, the number of maritime training institutes under the assurance of quality training by the Directorate General of Shipping DG(S) rose to 128 in 2005. India's share of global maritime human resources rose to 26950 officers and 75650 ratings, comprising an estimated $6 \%$ of the world's seafarers. The Eleventh Plan target for the marine training programme is to retain our $6 \%$ share of the global workforce and additionally supplying $20 \%$ of the current estimated shortages [2].

An outlay of Rs 5800 crore was provided in the Tenth Plan for Shipping Corporation of India (SCI). This included a sum of Rs 1290 crore as internal resources and Rs 4510 crore as external borrowings. Against this outlay, the expenditure was Rs. 2381 crore or $41.1 \%$ of the total outlay [2].

India has about $14500 \mathrm{~km}$ of navigable waterways which comprises rivers, canals, backwaters, creeks etc. About 45 million tons of cargo (2.5 BTKM) are being moved annually by Inland IWater transport (IWT). Inland Waterways Authority of India (IWAI) was constituted in 1986 for the development and regulation of inland waterways for shipping and navigation. However, most waterways suffer from navigational inadequacies such as shallow waters, narrow width, siltation, and bank erosion. Consequently, its operations are currently restricted to about $5200 \mathrm{~km}$ of major rivers and $485 \mathrm{~km}$ of canals suitable for mechanized craft operations [2].

Ports constitute the inter-modal interface between maritime and road and rail transport. India has a coastline of around $7517 \mathrm{~km}$ with 12 major ports and 187 notified non-major (minor/intermediate) ports along the coastline and Sea Islands. Almost $95 \%$ by volume and $70 \%$ by value of India's global merchandise trade is carried through the sea route. In 2006-07, the 12 major ports handled about $73 \%$ of the maritime cargo of the country. The balance $27 \%$ was handled by the non-major ports [2].Following table shows Indian shipping statistics.

\begin{tabular}{|c|c|c|c|c|c|c|}
\hline YEAR & \multicolumn{2}{|c|}{ COSTAL } & \multicolumn{2}{c|}{ OVERSEAS } & \multicolumn{2}{c|}{ TOTAL } \\
\hline & SHIPS & GT & SHIPS & GT & SHIPS & GT \\
\hline 15.08 .1947 & 48 & $1,19,000$ & 11 & 73000 & 59 & $1,92,000$ \\
\hline 01.04 .1951 & 71 & $2,05,699$ & 23 & $1,66,679$ & 94 & $3,72,378$ \\
\hline 01.04 .1961 & 97 & $3,13,694$ & 75 & $5,44,139$ & 172 & $8,59,833$ \\
\hline 01.04 .1971 & 66 & $2,30,822$ & 184 & $22,13,749$ & 250 & $24,44,571$ \\
\hline 01.04 .1981 & 59 & $2,49,633$ & 331 & $54,94,887$ & 390 & $57,40,520$ \\
\hline 01.04 .1982 & 64 & $2,87,412$ & 339 & $56,53,422$ & 403 & $59,40,834$ \\
\hline 01.04 .1983 & 69 & $3,40,904$ & 333 & $56,64,004$ & 402 & $60,40,908$ \\
\hline 01.04 .1984 & 72 & $3,37,264$ & 335 & $57,90,299$ & 407 & $61,27,563$ \\
\hline 01.04 .1985 & 99 & $3,42,336$ & 329 & $59,76,193$ & 428 & $63,18,529$ \\
\hline 01.04 .1986 & 100 & $3,01,896$ & 262 & $54,54,491$ & 362 & $57,56,337$ \\
\hline 01.04 .1987 & 120 & $4,13,632$ & 254 & $53,46,961$ & 374 & $57,60,593$ \\
\hline 01.04 .1988 & 129 & $4,43,331$ & 237 & $50,99,875$ & 366 & $55,43,206$ \\
\hline 01.04 .1989 & 146 & $4,55,244$ & 243 & $52,47,461$ & 389 & $57,02,705$ \\
\hline 01.04 .1990 & 152 & $5,12,467$ & 256 & $54,65,991$ & 408 & $59,78,258$ \\
\hline 01.04 .1991 & 163 & $5,23,733$ & 255 & $55,15,587$ & 418 & $60,39,320$ \\
\hline
\end{tabular}


A Case Study On Vulnerability Of Changing Business Environment At Cochin Port Trust

\begin{tabular}{|l|l|l|l|l|l|l|}
\hline 01.04 .1992 & 169 & $5,61,316$ & 243 & $53,45,663$ & 412 & $59,06,979$ \\
\hline 01.04 .1993 & 187 & $6,40,115$ & 250 & $56,33,142$ & 440 & $62,76,618$ \\
\hline 01.04 .1994 & 204 & $6,44,140$ & 238 & $56,35,246$ & 442 & $62,79,386$ \\
\hline 01.04 .1995 & 214 & $6,93,267$ & 237 & $58,61,882$ & 451 & $65,55,419$ \\
\hline 01.04 .1996 & 226 & $7,08,362$ & 254 & $63,91,891$ & 480 & $71,00,253$ \\
\hline 01.04 .1997 & 233 & $6,93,331$ & 248 & $62,21,749$ & 481 & $69,15,080$ \\
\hline 01.04 .1998 & 234 & $6,42,838$ & 244 & $62,00,318$ & 478 & $68,43,156$ \\
\hline 01.04 .1999 & 250 & $6,56,174$ & 240 & $62,12,021$ & 490 & $68,68,195$ \\
\hline 01.04 .2000 & 273 & $6,81,605$ & 240 & $62,31,361$ & 513 & $69,12,966$ \\
\hline 01.04 .2001 & 316 & $6,97,242$ & 230 & $61,19,357$ & 546 & $68,16,599$ \\
\hline 01.04 .2002 & 336 & $7,33,658$ & 224 & $60,87,279$ & 560 & $68,20,937$ \\
\hline 01.04 .2003 & 425 & $8,05,262$ & 191 & $53,72,297$ & 616 & $61,77,559$ \\
\hline 01.04 .2004 & 436 & $8,07,808$ & 203 & $61,36,398$ & 639 & $69,44,206$ \\
\hline 01.04 .2005 & 458 & $8,10,591$ & 228 & $72,02,364$ & 686 & $80,12,955$ \\
\hline 01.04 .2006 & 496 & $8,17,449$ & 243 & $76,46,971$ & 739 & $84,64,420$ \\
\hline 01.04 .2007 & 530 & $8,42,032$ & 257 & $77,53,153$ & 787 & $85,95,185$ \\
\hline 01.04 .2008 & 585 & $9,04,484$ & 282 & $80,86,107$ & 867 & $89,90,591$ \\
\hline 01.04 .2009 & 627 & $9,62,922$ & 298 & $83,20,217$ & 925 & $92,83,139$ \\
\hline 01.04 .2010 & 678 & $9,99,430$ & 327 & $86,89,133$ & 1003 & $96,88,563$ \\
\hline 31.03 .2011 & 722 & $10,24,674$ & 349 & $94,25,631$ & 1071 & 10450305 \\
\hline & & & & & & \\
\hline
\end{tabular}

Table 1 Indian Shipping Statistics

Source: Ministry of shipping statistics

\section{An Overview On Cochin Port Trust}

2.1 FINANCIAL POSITION

The profit and loss account for 2010-11 closed with a deficit of Rs.8609 lakhs. The operating income increased by $18.96 \%$ to Rs.27608 lakhs during 2010-11 from Rs.23208 lakhs during 2009-10. The operating expenditure increased from Rs.23295 lakhs in 2009-10 to Rs.27450 lakhs in 2010-11 registering an increase of 17.83\%.

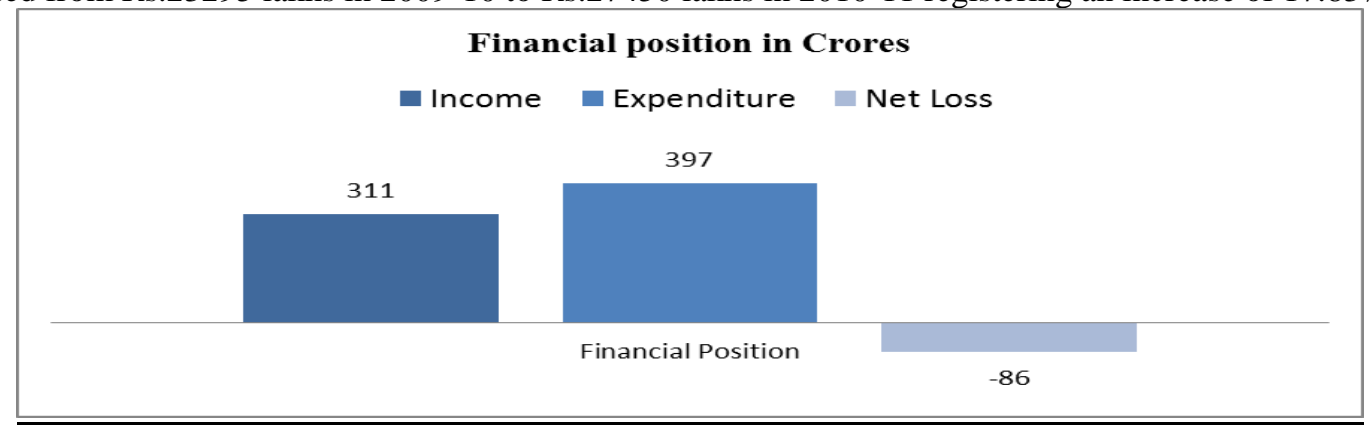

Figure 1: Financial Positions 2010-2011

Source: Administrative Report 2010-2011

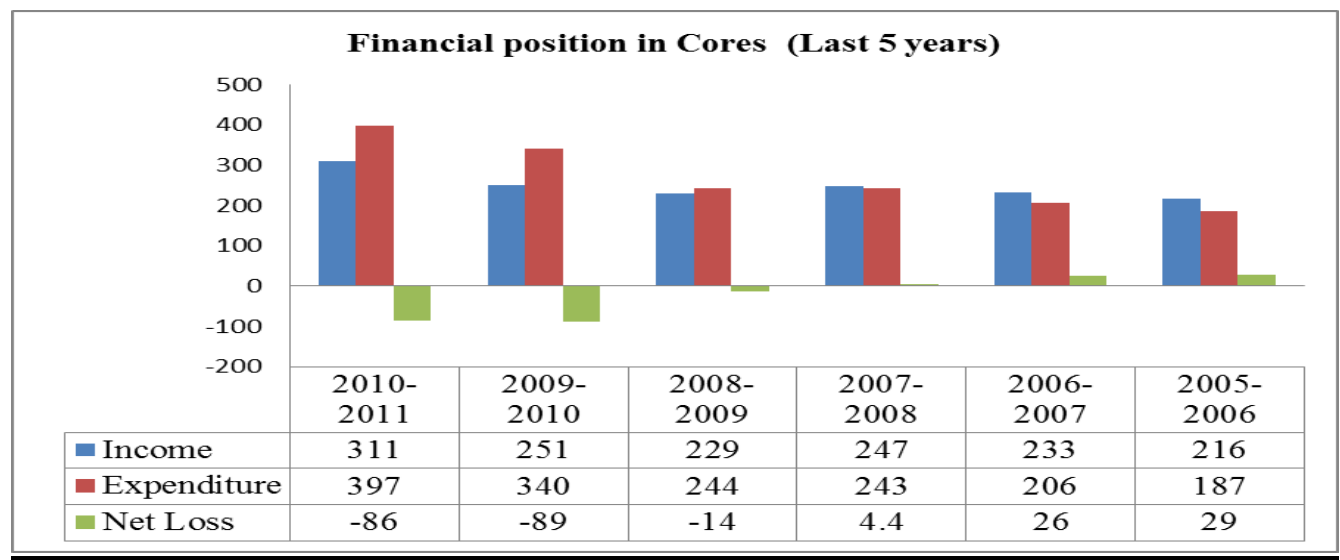

Figure 2: Financial Positions in cores last 5-years $\quad$ Source: Administrative Report 2005-2011 


\section{Distribution of Revenue}

- Estate Rentals $\approx$ Cargo handling \& storage charges $\approx$ Port \& Dock charges

Figure 3: Distribution of revenue

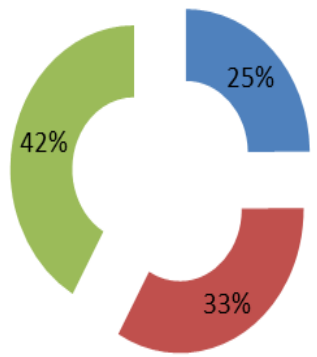

\subsection{TRAFFIC HANDLED}

The total traffic handled by the Cochin Port Trust during the year recorded an increase of $2.25 \%$ to 178.73 lakhs tones as against 174.29 lakhs tones handled in the preceding year as shown in figure.

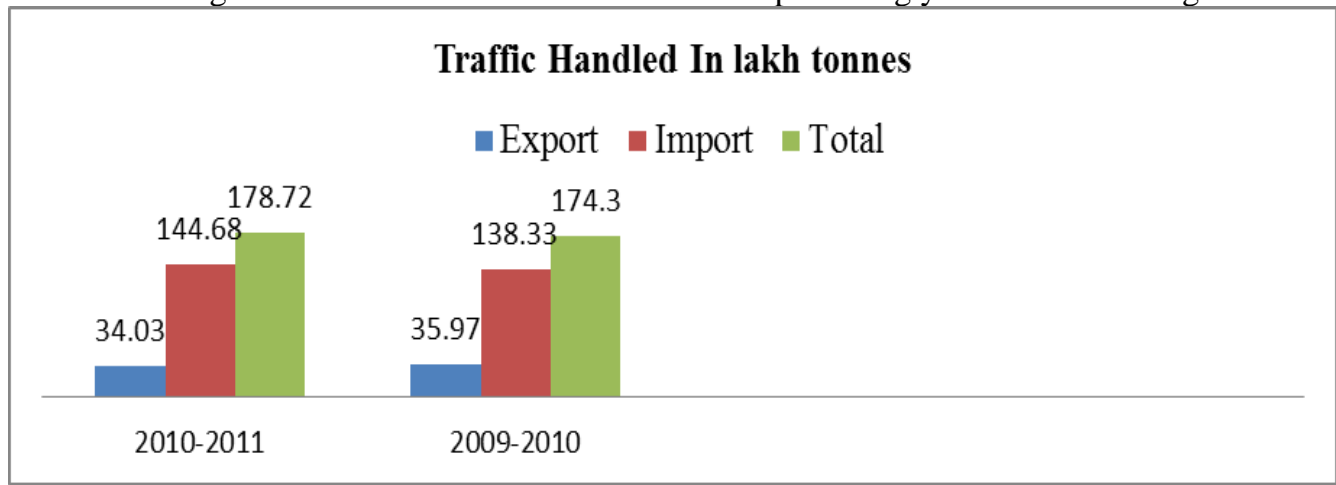

Figure 4: Traffic handled in Cochin Port Trust. A comparison Source: Administrative Report 20102011

Following two figures illustrate the composition of cargo and type of cargo handled through Cochin port for the last year

Percentage Compositon of Traffic during 2010-2011

घ Costal Exports $\quad$ Forgine Exports $\backsim$ Costal Imports $\backsim$ Forgine Imports

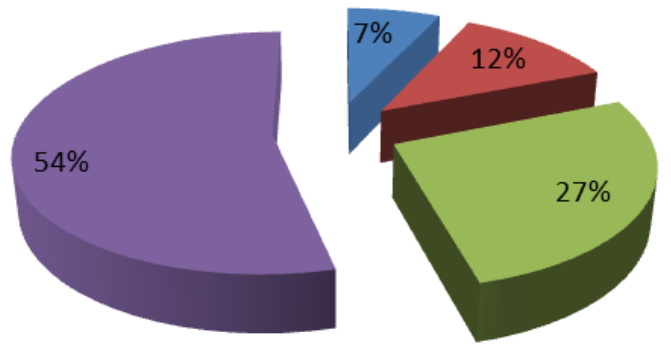

Figure 5: Percentage Composition of Traffic during 2010-2011

Source: Administrative Report 20102011 


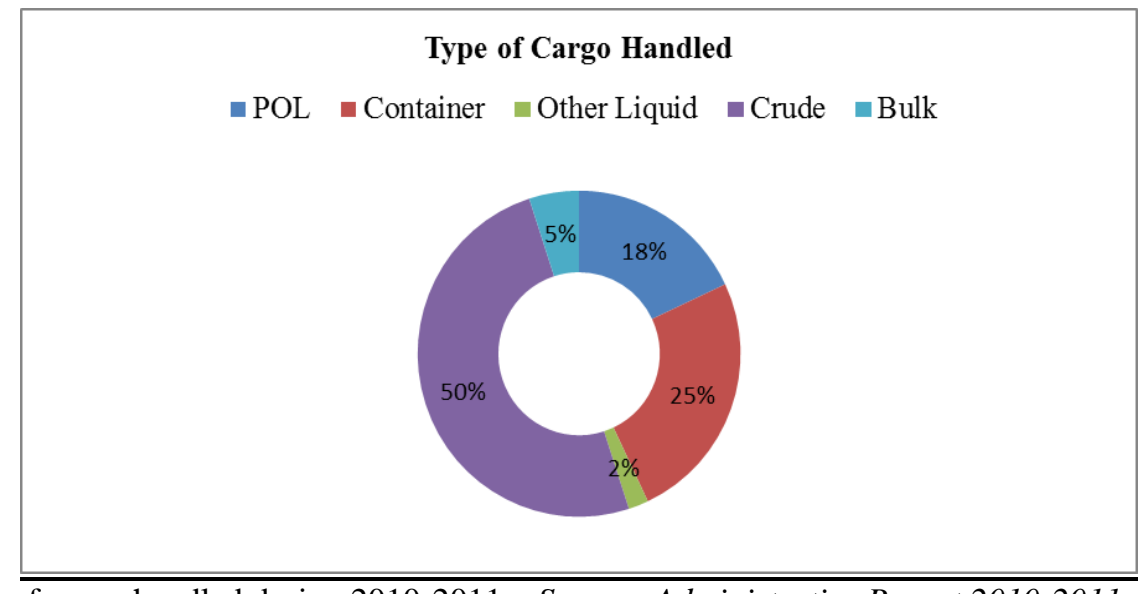

Figure 6: Type of cargo handled during 2010-2011 Source: Administrative Report 2010-2011

\section{Identifying Causes Of Poor Financial And Traffic Performance}

\subsection{THE TAGUCHI PHILOSOPHY}

According to Taguchi "Quality is the loss imparted to the society from the time a product is shipped" Typical example of loss to the society include failure to meet the customer requirements and unsatisfactory performance that leads to loss of goodwill and reduced market share and failure of an organization etc.

Cause-and-effect diagrams can reveal key relationships among various variables, and the possible causes provide additional insight into process behavior. In this study a cause and Effect diagram is created to analyze the effect of various causes. And it also studies how these will create an effect of loss to the society.

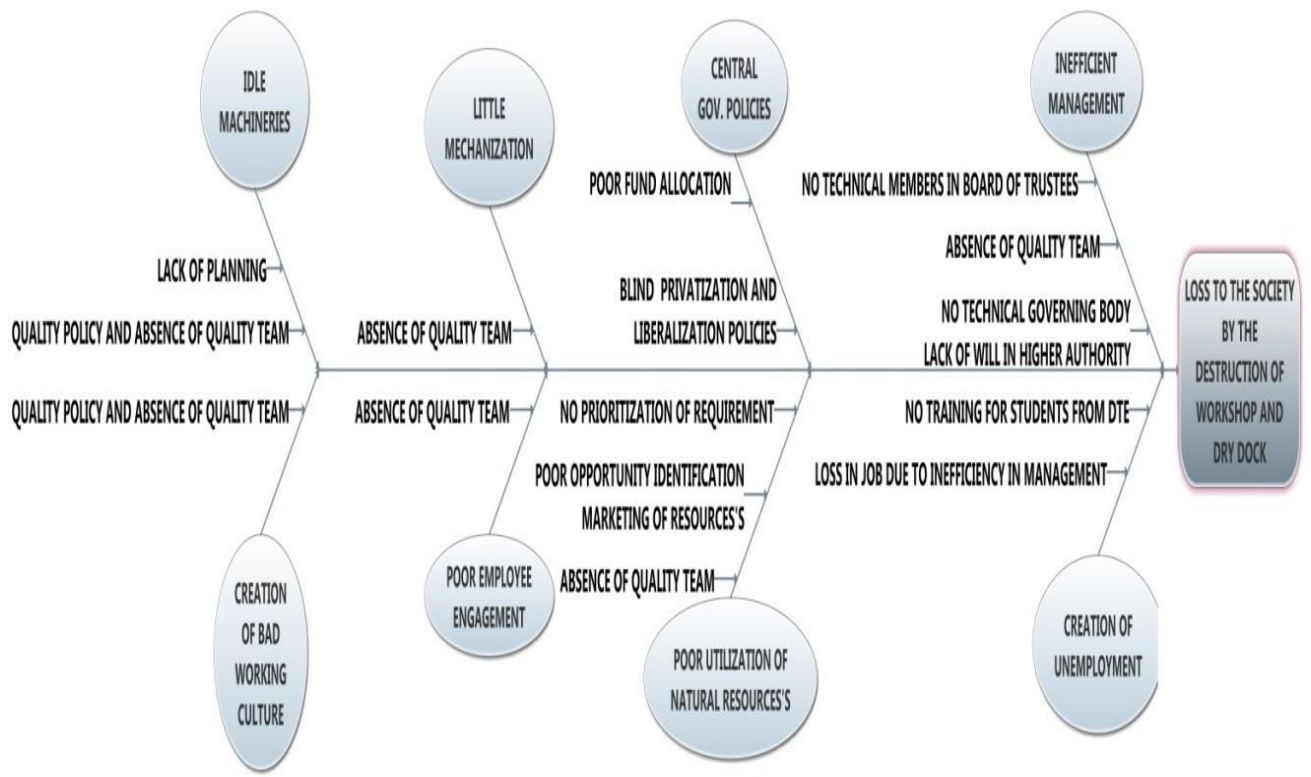

Figure 7: Causes and Effect Diagram

\subsection{ANALYSING THE CAUSES}

- Central Government policies

BOT contract for establishing the ICTT has been executed with the BOT operator M/s India Gateway Terminal Private Limited (IGT), a subsidiary of M/s Dubai port World (DPW) on 31.1.2005.The existing Rajiv Gandhi Container Terminal (RGCT) taken over by M/s IGT on 1st April 2005 till the commencing of new terminal at Vallarpadam. The total project cost of ICTT is 3000 Crores. Cochin Port Trust is only eligible for $33 \%$ of revenue from this project .The remaining $66 \%$ will goes to DP World.

The main two issues identified as the part of this study in this agreement they are, 
* After the commencement of operation in ICTT at Vallarpadam the same will be operated by DPW for the coming 30 years .For these 30 years the Cochin Port Trust is not allowed to use the RGCT for handling the containers. It will be a huge loss to the nation.

* The dredging of Outer Channel, Inner Chanel including the premises of the ICTT berth is coming under the responsibility of the Cochin Port Trust. Cochin port Trust has only one dredger called Nehru Shatabdi with very limited capacity. In the present situation the dredging cost will be a great liability for the port trust. The last year Cochin Port paid around 90 crores to a third party towards the dredging cost.

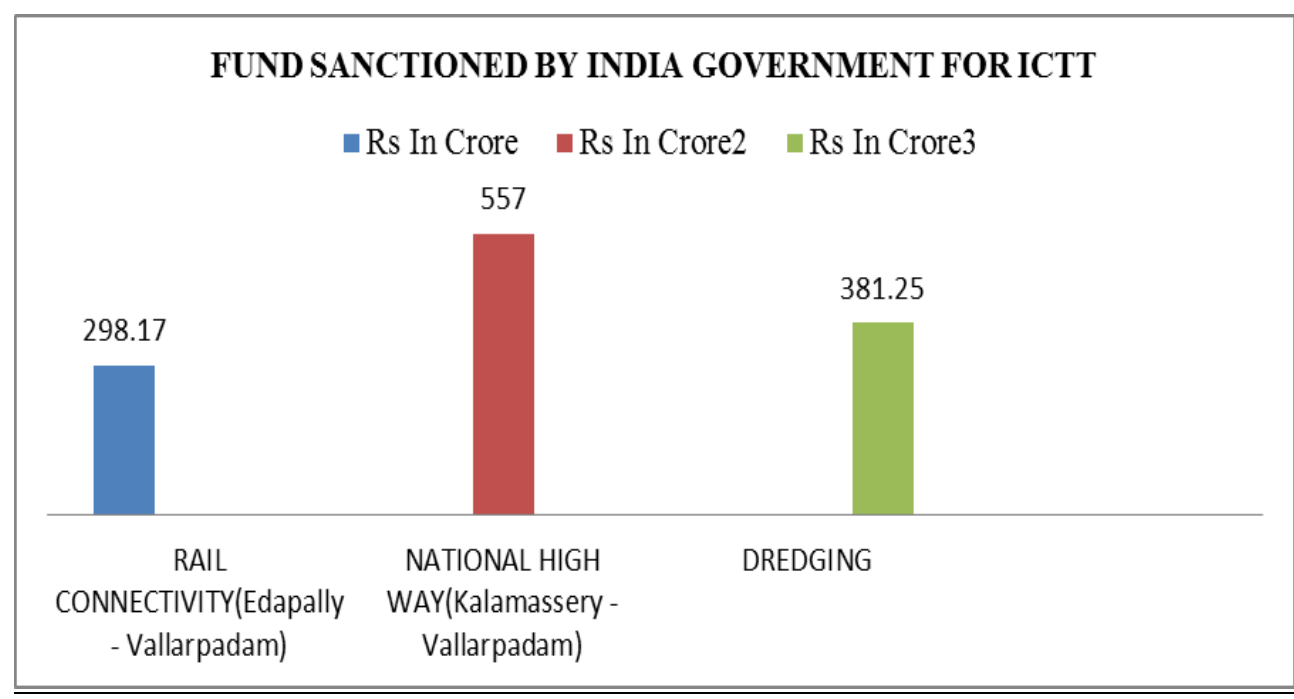

Figure 8: Fund sanctioned by the Indian Government $\quad$ Source: Administrative Report 2010-11 Concluding this discussion by identifying the factors that, Government should raise more fund for the development of our public sector companies. Government has to more vigilant in their policies on privatization. While privatizing the national assets it should be favorable for national interest.

\section{○ Creation of Unemployment}

Unemployment is the world's fastest-rising worry, Corruption and poverty still ranked the highest. Issues associated with inflation, such as higher food and energy prices are some of the issues should be addressed by Governments of all countries. For a country like India, even though GDP growth is either increasing or showing a steady growth. The percentage of unemployed people in the Country are still increasing. The following figures will give an idea about this situation.

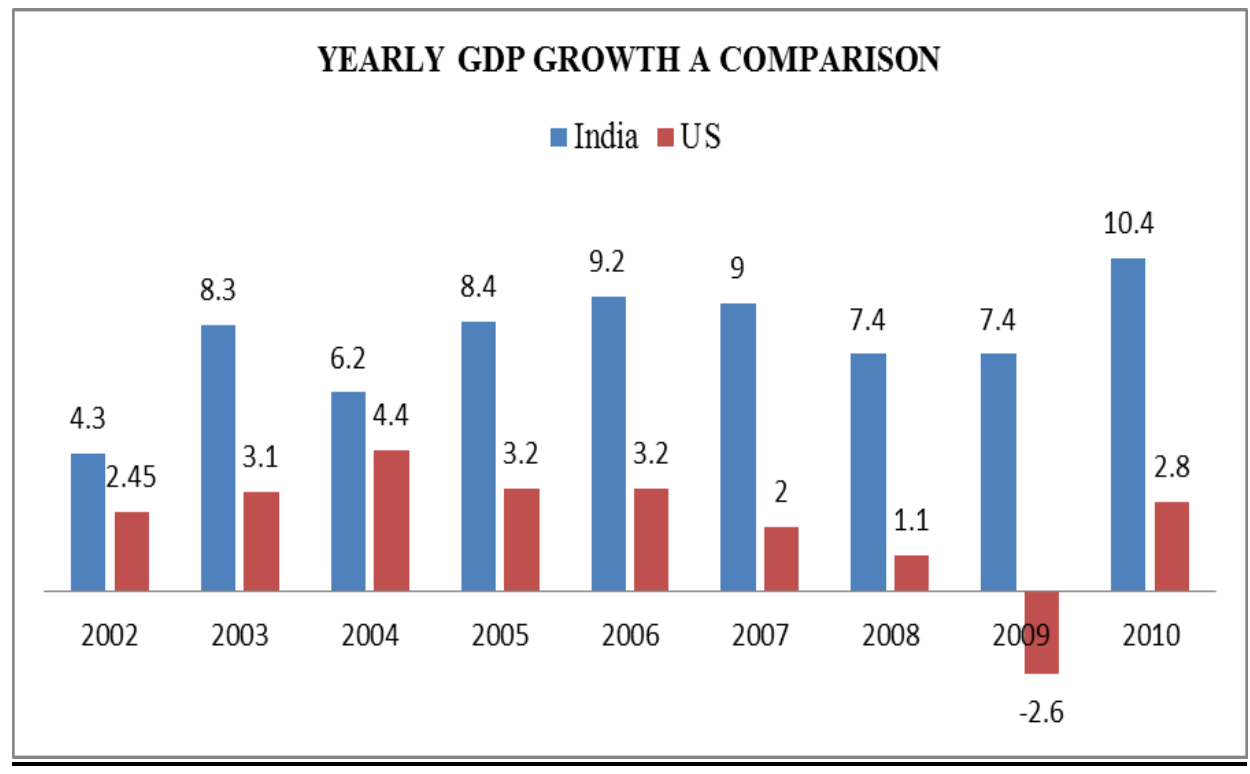

Figure 9: Yearly GDP growth rate

Source: Website www.indexmundi.com 


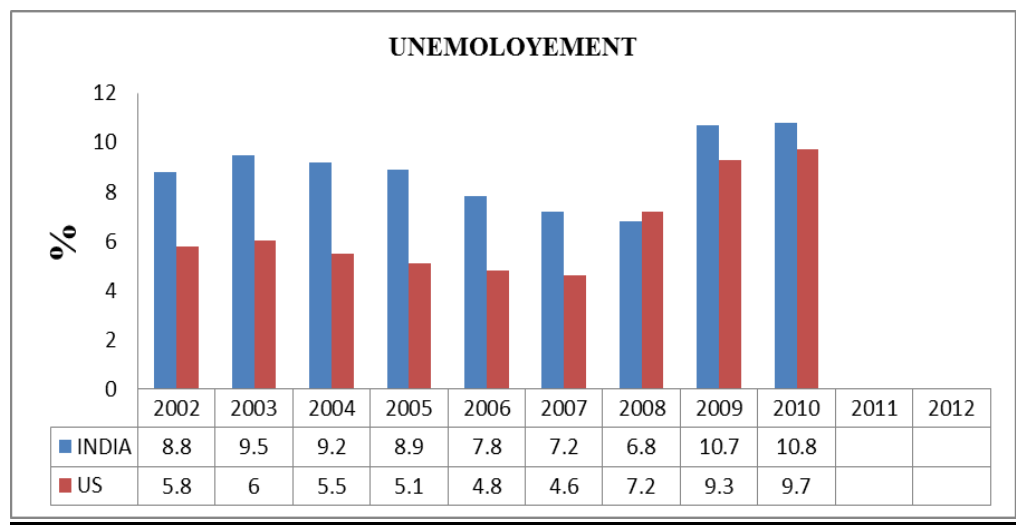

Figure 9: Comparisons on Unemployment India \& US Source: Website www.indexmundi.com

From the above table we can identify that the world economy is facing the big problem associated with unemployment .An organization like Cochin Port Trust capable to address this issue for our nation now showing its negative approach on this issue. It will be clearly identified from the following figure which shows the lost employment opportunity in percentage.

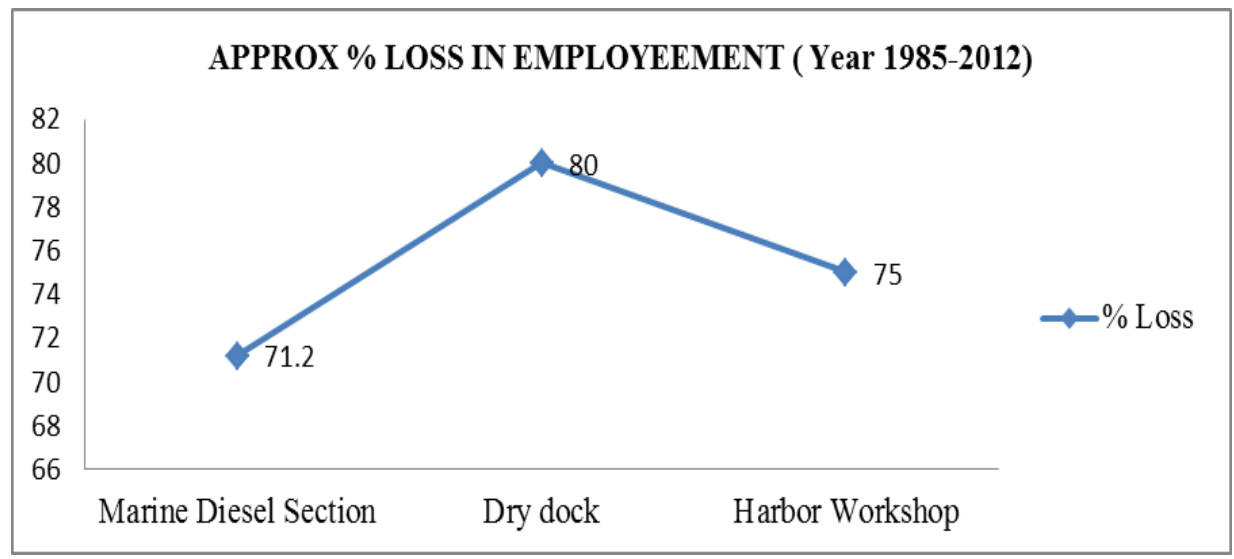

Figure 10: Lost Employment Opportunity in Cochin Port Trust

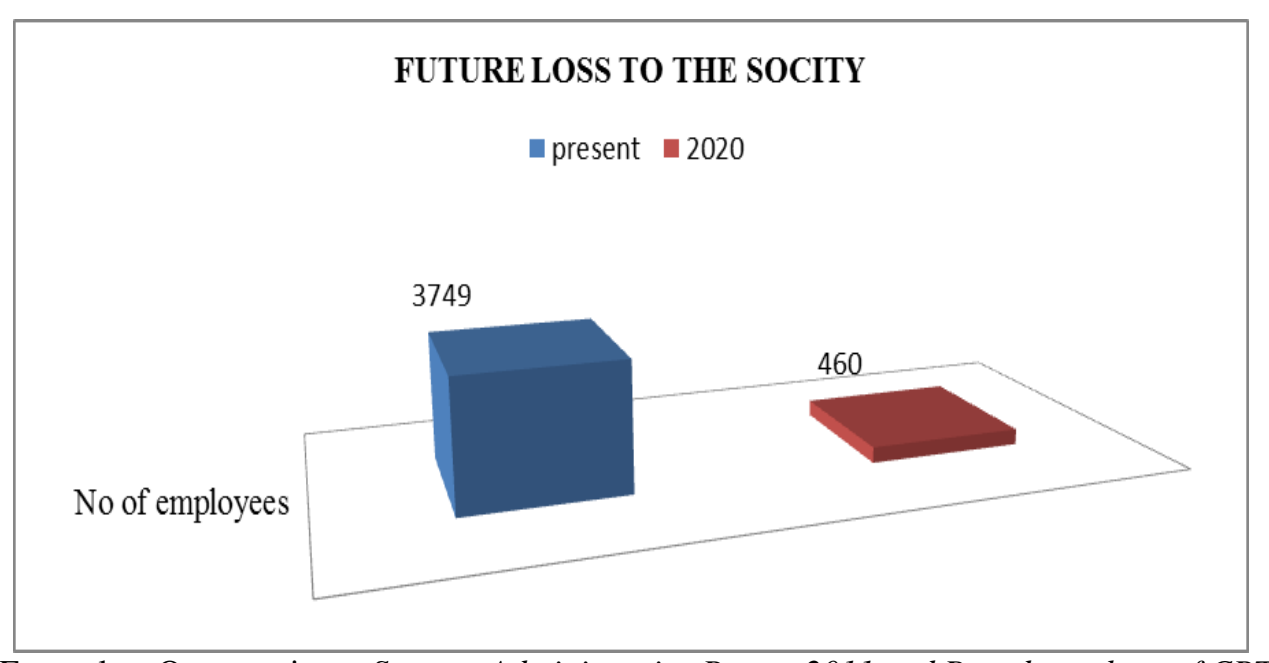

Figure 11: Future lost Opportunity Source: Administrative Report 2011 and Board members of CPT

Concluding this discussion by identifying the following factors, which have affected the growth of the industry. They are the absence of a technical governing body, and the absence of a quality circle followed by the Governing body with a vision towards the future of this organization. It leads to the inefficiency in the management contributed to poor utilization and the identification of the strength of the available natural resources, and its importance in the changing business environment. 


\section{○ Poor Utilization of Natural Recourses}

* Commercial Importance of Dry Dock and Workshop in the Changing Business environment

The dry dock and workshop are constructed for the maintenance of vessels used by the Cochin Port alone. The present changes in business environment offer the Cochin Port Trust to generate revenue from harbor workshop and dry dock. Effective utilization this dock and workshop area will be a major source of income for the Cochin Port Trust in the future. It can be well marketed for the maintenance of private vessels which are operated through the port hinterland. The same time it will help to port trust to create employment opportunity for the educated youth of Kerala. The major advantage of Cochin Port Trust is the proximity to the Cochin Shipyard. It is possible to collaborate with Shipyard in several areas. The other main business opportunities depend on following projects.

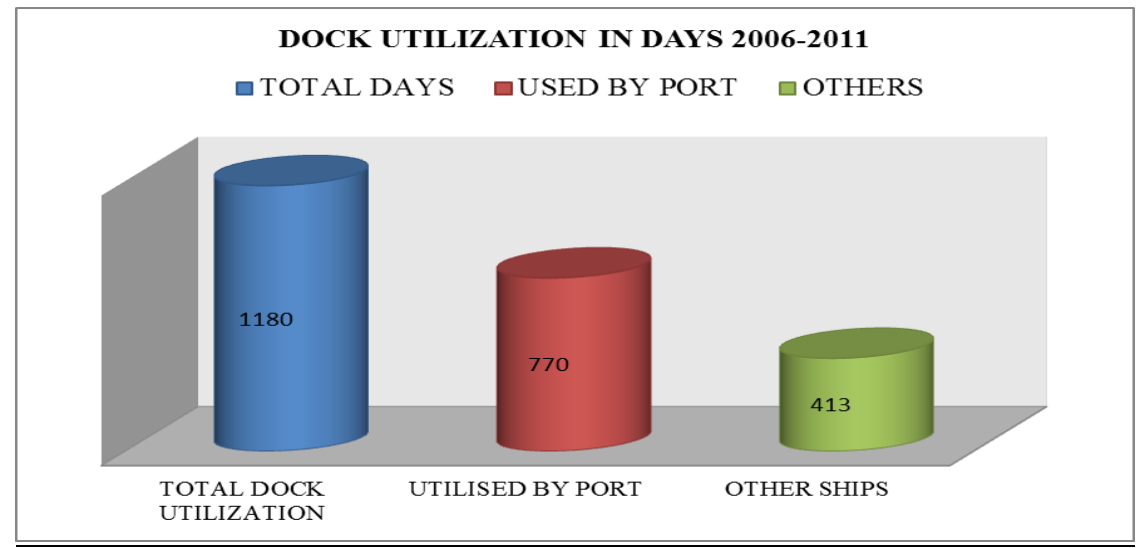

Figure 12: Dock Utilization of vessels 2006-11

Anyway Central Government is planning waive the cabotage rule for ICTT Vallarpadam .It will allow the foreign ships to handle cargo in the Cochin Port Trusts hinterland .The port can use the Dry dock and workshop for the maintenance of these vessels ,by taking the advantage of the e-port facility. The above figure shows the number of vessels entered in Cochin Port Trust for the last few years'. The relaxation of Cabotage rule will defiantly increase the above statistics.

\section{○ Little Mechanization}

During the year 2010-11 the overall pre-berthing waiting time increased to 24.6 Hrs. as against 20.31 Hrs. in preceding year. And the average turnaround time of ships having cargo work increased to 2.20 days during the year from 2.08 days in the preceding year. This is due to the insufficient number of material handling equipment in the port operation.

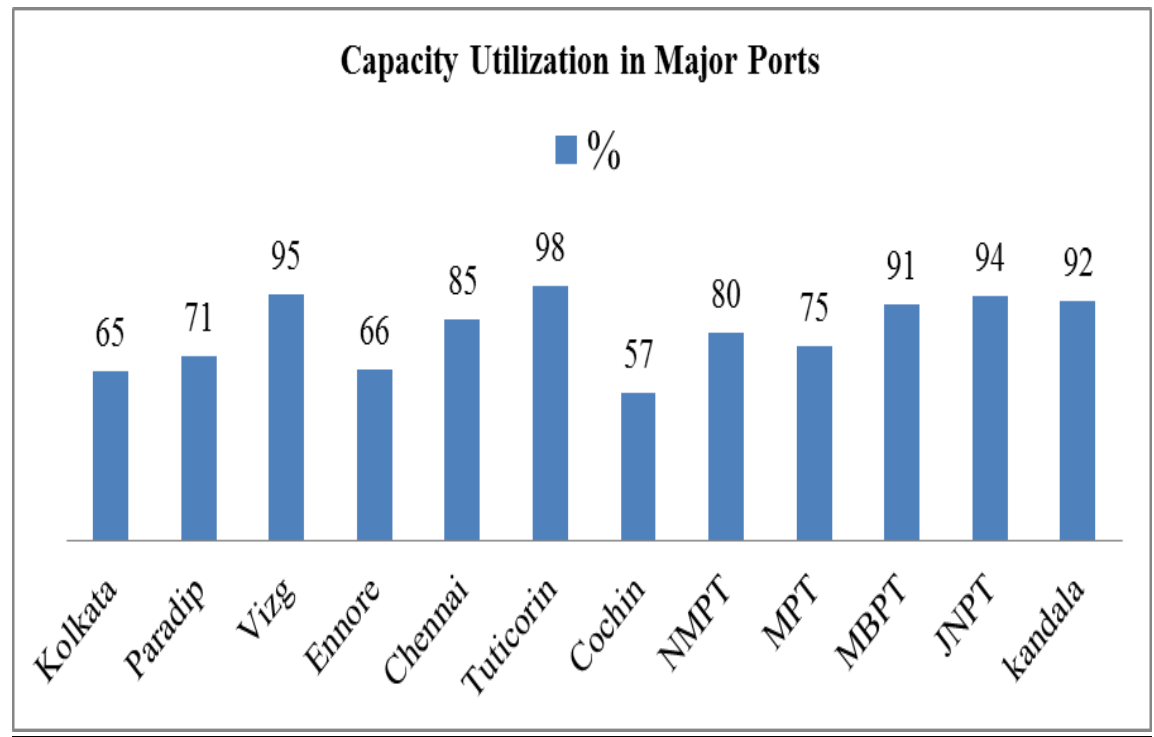

Figure 13: Capacity Utilized in Major Port Source: National Conference on Ports and Shipping 2011 Background paper 
From the above table the capacity utilization of CPT compared to other major port trust is very low because of the insufficient material handling equipment's. Concluding this discussion by identifying the absence of a quality circle .The absence affected the organization in its all area of operation.And it will be a loss to the society.

\section{$\circ \quad$ Inefficiency in Management}

The Board of Trustees is an Autonomous body Appointed by the central government of India. The Board of trustees consists of eighteen members including the Chairman and Deputy Chairman appointed by Central government. The other sixteen members are also appointed by Central government .Out of this sixteen twelve members should be from the following area. Ministry of shipping, Indian Railway, DG shipping, Indian Navy, Coast guard, State Government, Department of Revenue, Labors employed in port, Major users and terminal operators, Ship owners / Agents, Exporters / Importers. The remaining four will be from other interest. The main issue associated with this system is that even though the board is an autonomous body due to the appointment structure they are forced to follow the central government policies rather than the interest of the port. Another important point to be considered is that none of the members are neither experts in port operation or port business. It will badly affect decision making in port management like opportunity identification, Technical advancement required etc. Concluding the discussion with the identifying the absence of a Technical Governing body and a Quality Circle.

\section{- Poor Employee Engagement, Creation of bad working culture and idle machineries}

Data's are collected by conducting a survey among the workers using a pre-tested questionnaire with a sample size of 20 .Sampling method used for the survey is a judgment sampling method in non-probability sampling technique.

The effectiveness of the employee engagement depends upon the degree to which the employee is the part of the decision-making process and their ideas are incorporated into the final plan. It generates selfresponsibility among the employees. This sense of self -responsibility instills the sense of ownership in the employee's mind and they will feel that they actually own the job and accountabilities for each and every decision. Employee engagement is not a one-time process or a short-term initiative; it is an on-going and steady process. And it will be well managed in the presence of a quality circle.

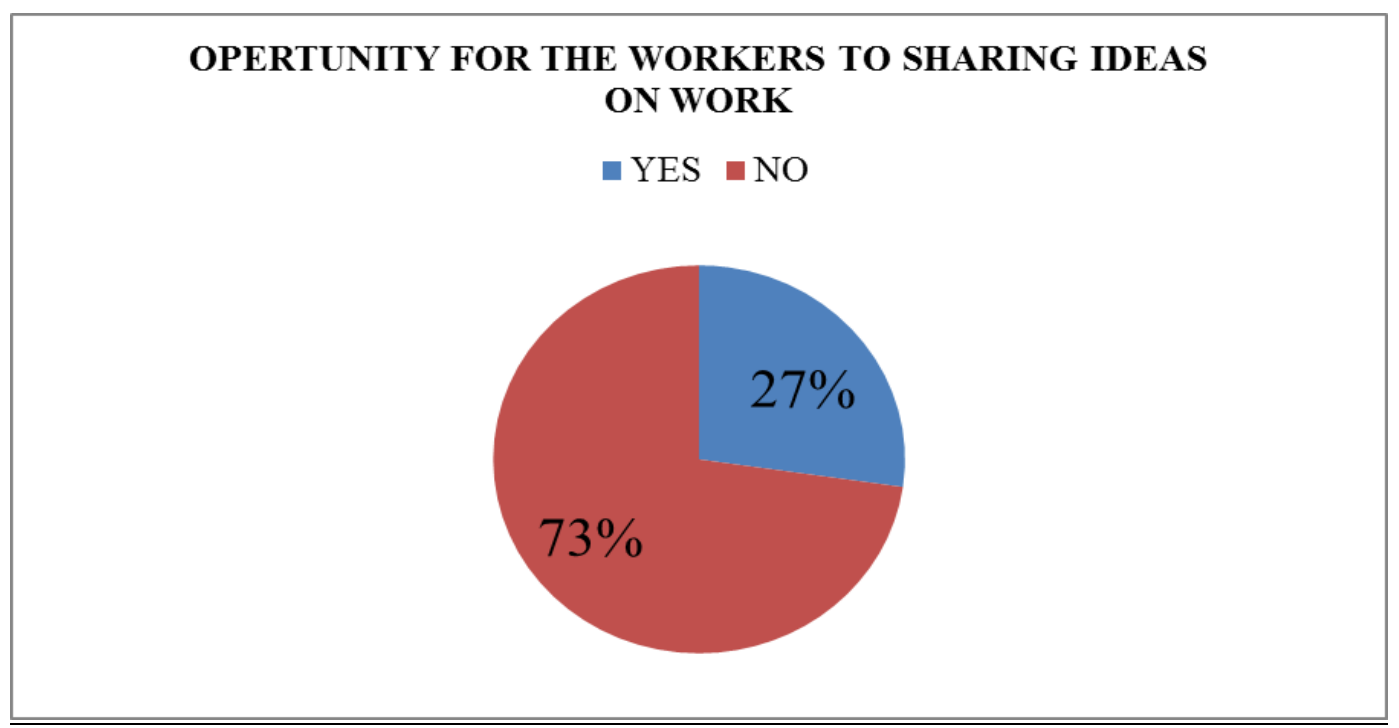

Figure 14: \% opportunity for workers to share ideas 


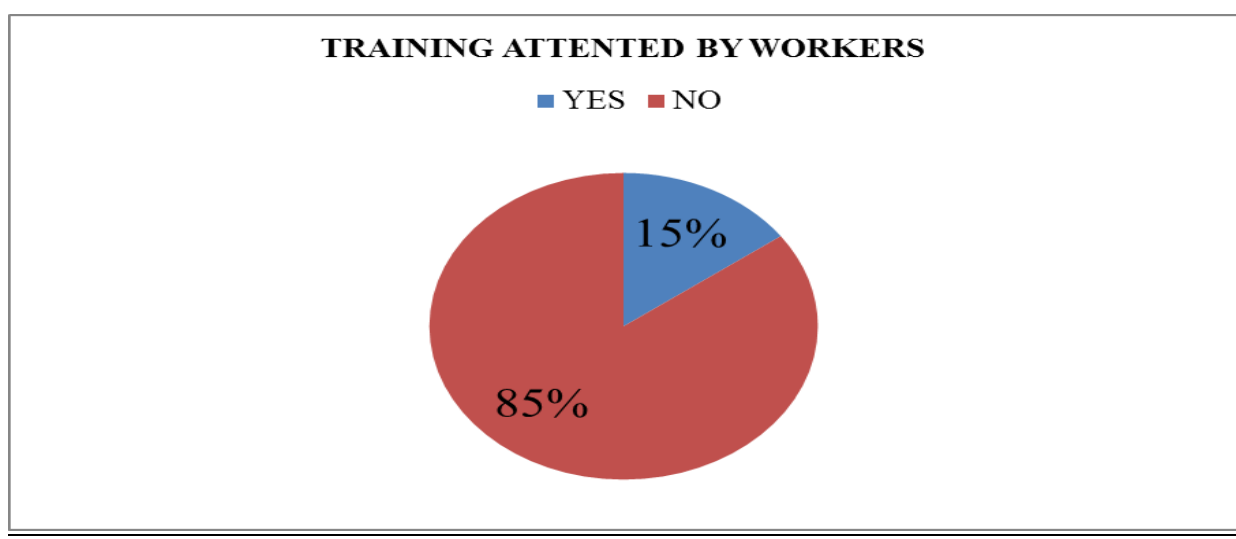

Figure 14: Training attended by workers

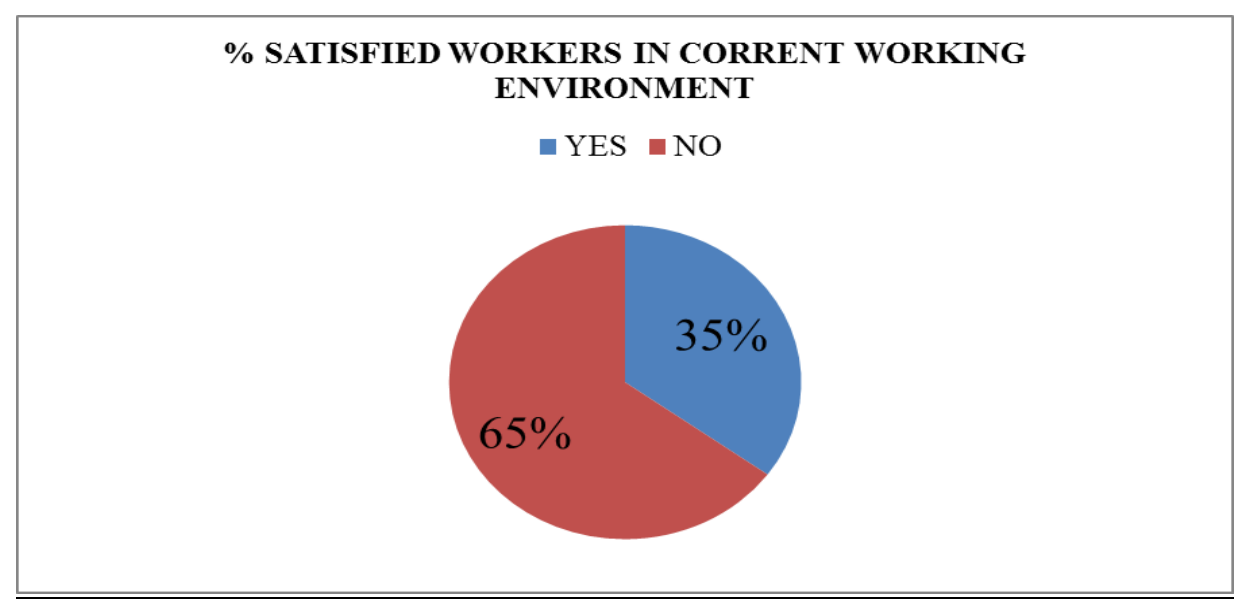

Figure 15: \% Satisfied Employees

\section{Refined Cause And Effect Diagram}

A refined cause and effect diagram is created by considering the causes which have an impact on other causes or tackling these causes will eliminate other causes. The $\mathrm{c}$ identified causes that the Central government policies and little mechanization are not addressing the this stage of the study. The major three causes Inefficiency in Management, Poor utilization of natural resources; Poor employee engagement should be tackled in the bright future of the organization. It can be done only by modifying the present organizational structure

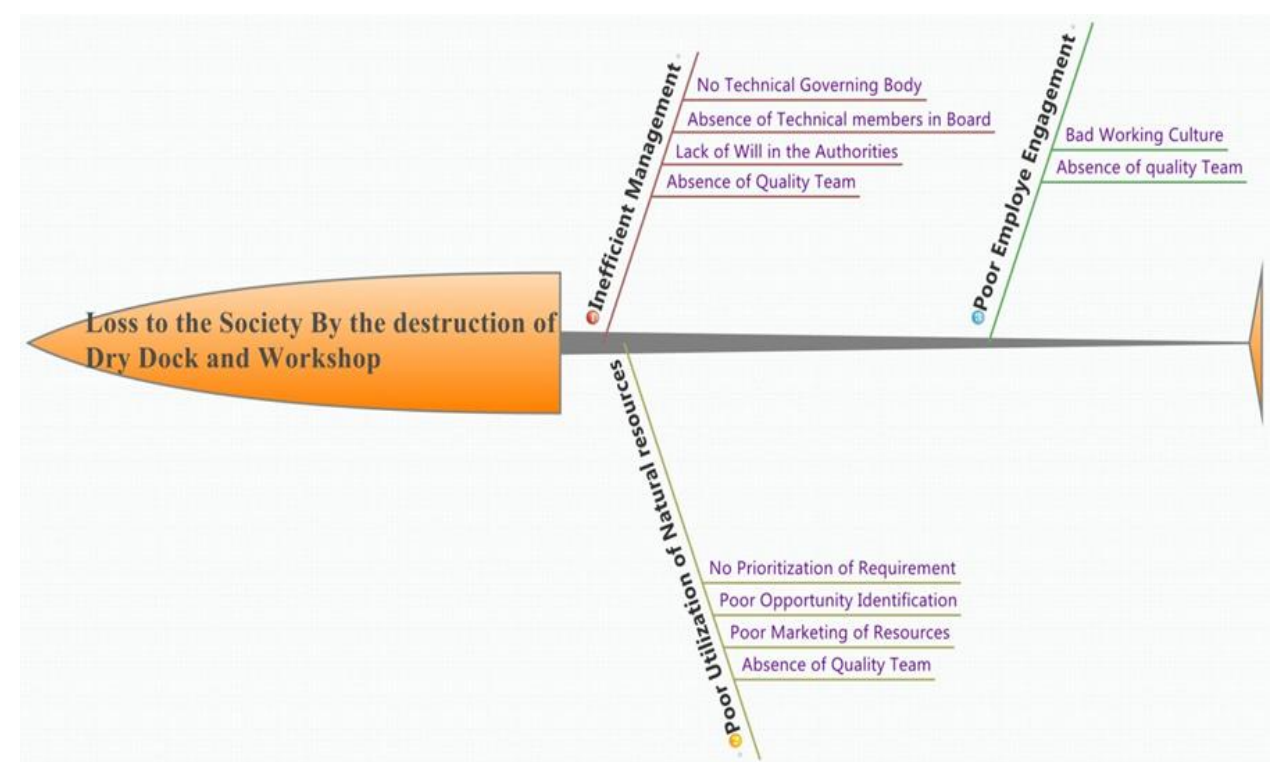

Figure 16: Refined Cause and Effect diagram 
V. Summery, Discussion and Solution

\subsection{SUMMERY PORT PERFORMANCE}

○ Financial performance of Port

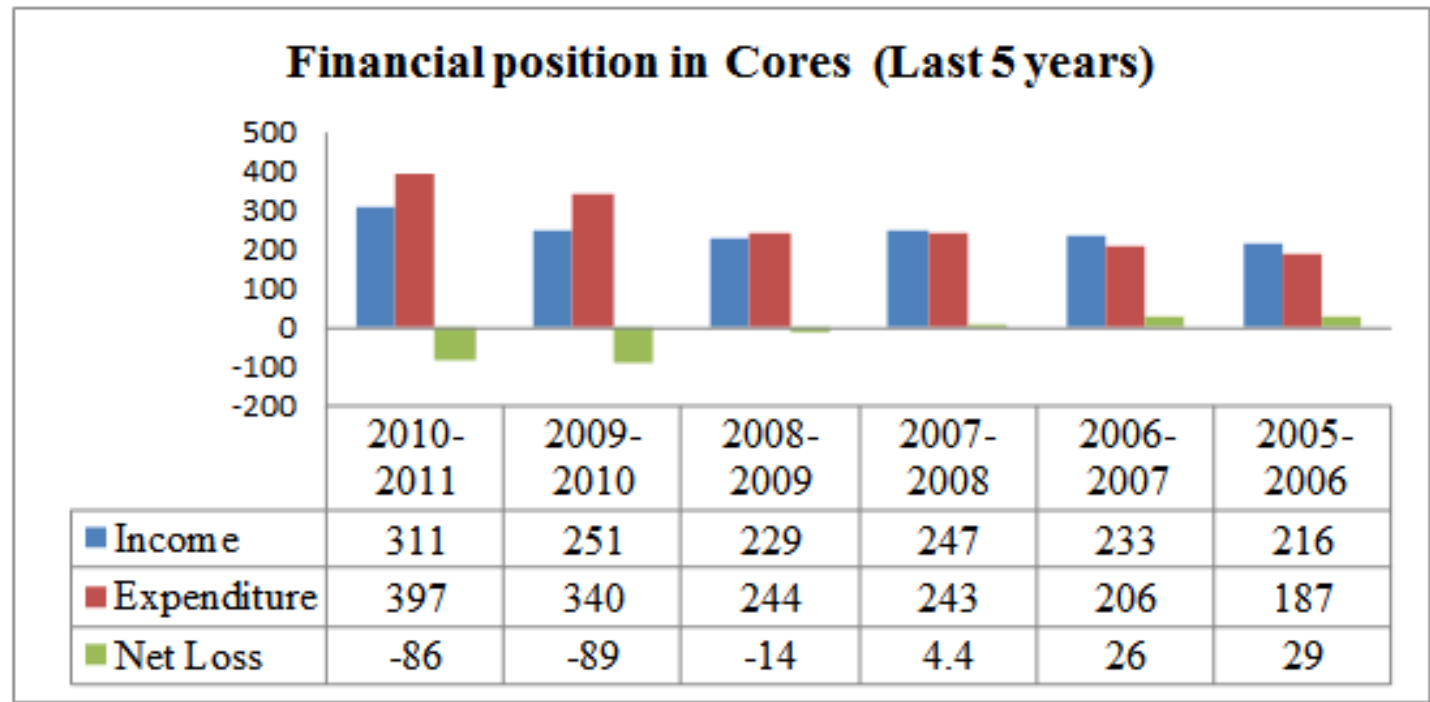

Figure 17: Financial position

Source: Administrative reports

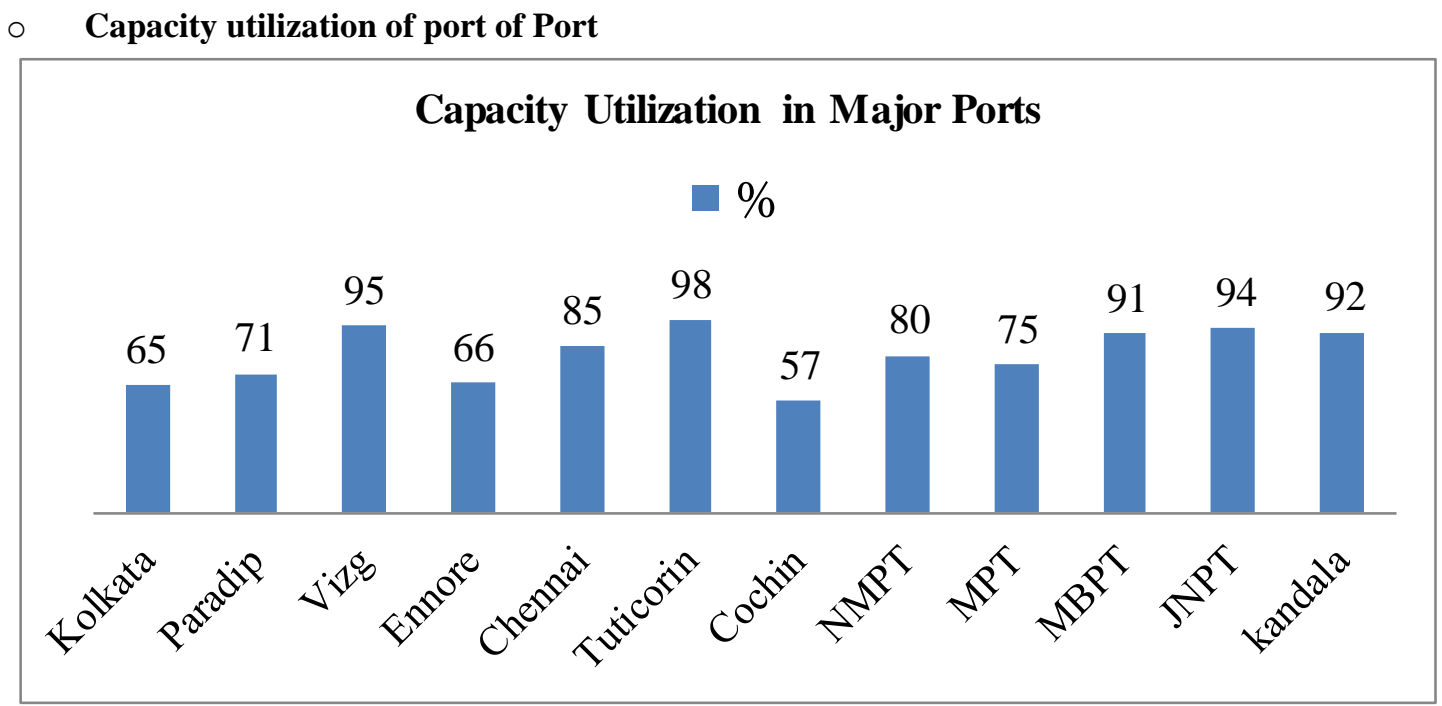

Figure 18: Capacity Utilization

Source: National Conference on Ports and Shipping 2011 Background paper 


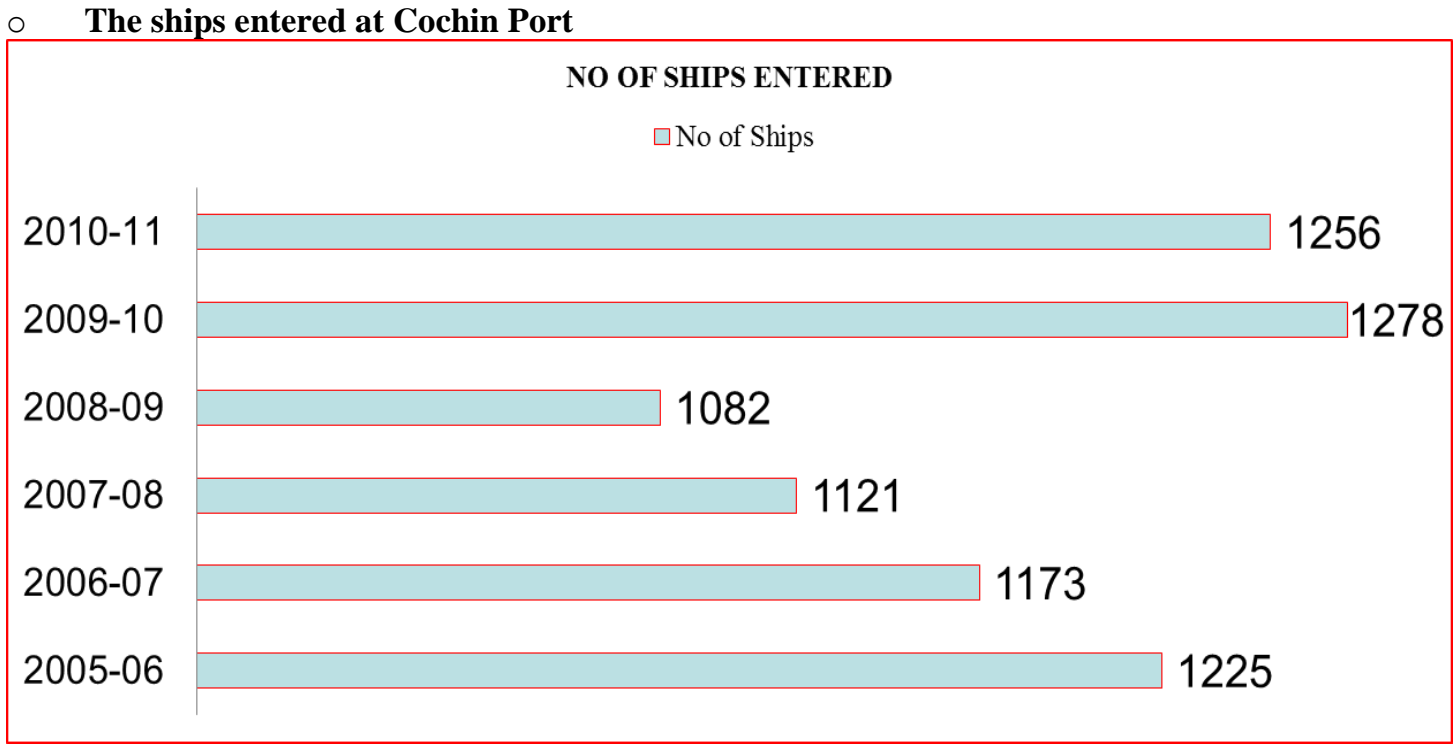

Figure 19: No of ships entered in Cochin Port Trust

Source: Administrative reports 2010-2011

\begin{tabular}{|c|c|c|c|}
\hline NO & Type of Equipment & Availability & Capacity in Tones \\
\hline 1 & $\begin{array}{l}\text { Heavy Duty Reach } \\
\text { Stacker }\end{array}$ & 1 & 45 \\
\hline 2 & Mobile Crane & 1 & 10 \\
\hline 3 & Forklift Trucks & 20 & 3 \\
\hline
\end{tabular}

\subsection{DISCUSSION ON SUMMERY- PORT PERFORMANCE}

This study identifies the absence of quality circle in all the areas of the port operation, which can be seen from the present organizational structure of the Cochin Port trust shown in the following figure. The head of the department of the organization will not get sufficient time to ensure the quality and effective operation of the organization, also due to the reason that the Chairman and Deputy Chairman are nominated members by the Central government it also brings the issue that the nominated persons may not be experienced person in port operation and port business, most of the cases his core competency will be limited only in administrative activities. 
1. Dwell Time: The duration for which an entity stays in the port for service is called the dwell time of the entity. In the port parlance, the entities are mainly the vessel and cargo / containers. Any reduction in dwell time would reduce transaction costs and also increase the capacity of the existing port infrastructure.

2. Pre-Berthing Detention (PBD): This is the time taken by a ship from its arrival at the anchorage (reporting station) till it starts its movement to the working berth, i.e. operational berth. Pre-Berthing Detention is a component of Turn Round Time and any increase in the PBD correspondingly increases the Turn Round Time.

3. Non-Working Time of Vessels at Berth: Non-Working Time is defined as the sum of the idle time from the time of berthing to start of work, idle time during ship operations and idle time taken from the time of completion of operations to sailing from berth together.

4. Turn Round Time (TRT): Turn Round Time of a vessel refers to the time the vessel reports at the anchorage at the time it sails out from the berth.

\begin{tabular}{|l|c|c|}
\hline \multicolumn{1}{|c|}{} & Average TRT & Average PBD \\
\hline Liquid bulk & 1.98 & 2.06 \\
\hline Dry bulk & 5.98 & 3.99 \\
\hline Break bulk & 3.74 & 0.00 \\
\hline
\end{tabular}

Table 3 Performance of CPT in terms of above parameters

We are not considering the turnaround time for liquid bulk because the major customer in this area is a Cochin Refinery Ltd at present COT is handled by Cochin Refinery and Cochin port trust is taking care of the preberthing activities this can also be reduced by effective coordination in Mechanical, Marine and Traffic departments.

The turnaround time for the other two cargos should be reduced for better financial performance, increased efficiency and improved capacity utilization. The reduction in turnaround time can only be achieved by the increasing the cargo handling equipment available at the port operation. In the present situation only ships with inbuilt cranes can approach the port trust due to non-availability of that equipment's.

\subsection{PROPOSED MATERIAL HANDLING EQUIPMENT}

The turnaround time of dry bulk cargo is very high (5.89 days) which must be reduced because the dry bulk area Cochin port getting the help from India's largest fertilizer manufacturer FACT in all aspects, so it is proposed to concentrate more on the dry bulk area.

\begin{tabular}{|l|l|}
\hline Distribution of Cargo handled 2010-2011 & \\
\hline Dry bulk & 10.27 lakh tons(1 MT) \\
\hline Break bulk & 1.1 lakh tons \\
\hline
\end{tabular}

Table 4: Distribution of cargo handled at CPT Source: website Cochin Port Trust 
At the present situation Cochin port trust having only one harbor mobile crane with 10 ton capacity. Assuming that the port has to be handling 8.8 Million Tons (MT) 2020-21 and 13.7 MT by 2027-28 In order to meet the traffic forecast for the next 10 to 14 years. It is proposed to purchase a Harbour Mobile crane with a capacity of $120 \mathrm{~T}$.

The other main points made in the proposal are as under

\section{Assumptions:}

On stream days considered in a year 302 days

Equipment availability per day 21 hours

Material handling equipment efficiency

$85 \%$

No cycles per crane

20

\section{Description of Crane:}

\begin{tabular}{|l|l|}
\hline Details & $120 \mathrm{HMC}$ \\
\hline Maximum reach required & $34 \mathrm{~m}$ \\
\hline Grab weight & $20 \mathrm{~T}$ \\
\hline Load/move at 11 to $19 \mathrm{~m}$ & $75 \mathrm{~T}$ \\
\hline Load/move at $34 \mathrm{~m}$ & $39 \mathrm{~T}$ \\
\hline $\begin{array}{l}\text { Average load/move } \\
\text { (Excluding the grab weight) }\end{array}$ & $37 \mathrm{~T} / \mathrm{grab}$ \\
\hline Handling rate/hour & $37 * 20=740 \mathrm{~T} / \mathrm{hr}$. \\
\hline Equipment efficiency & $85 \%$ \\
\hline Handling capacity / hour & $740 * 0.85=629 \mathrm{~T} / \mathrm{hour}$ \\
\hline Handling capacity / day & $629 * 21=13209 \mathrm{~T} /$ day \\
\hline Annual handling capacity & $13209 * 300=3,989,118$ i.e. 3.98 MT \\
\hline
\end{tabular}

Table 5: Details of crane Source: Tariff Authority for Major Ports 


\section{Operating Cost:}

In this connection, in the first year of operation the equipment will be covered by warranty and hence the maintenance cost is considered from the second year onwards. Based on the TAMP guidelines, the different items of operating costs are considered. It has furnished a cost statement for $120 \mathrm{~T}$ HMC along with the group. The main cost elements considered by the port are tabulated below:

\begin{tabular}{|l|l|l|l|}
\hline Si No & Particulars & Working & 120 T HMC with Grab \\
\hline 1 & Capital Cost & & 2352.5 lakhs \\
\hline 2 & Operating and Maintenance Cost & & \\
\hline 2. a & Fuel & $\begin{array}{l}4000 \text { hours } \\
(701 \text { trs/hour@ Rs.63) }\end{array}$ & 176.4 lakhs \\
\hline 2. b & Repair and Maintenance Cost & $5 \%$ of Capital Cost & 117.625 lakhs \\
\hline $2 . \mathrm{c}$ & Insurance & $1 \%$ of Capital cost & 23.52 lakhs \\
\hline $2 . \mathrm{d}$ & Depreciation & $\begin{array}{l}10.34 \% \text { on capital cost } \\
(\text { As per norms } \\
\text { Prescribed in } \\
\text { Companies Act) }\end{array}$ & 243.24 lakhs \\
\hline 3 & Total Cost & $5 \%$ of Capital Cost & 117.625 lakhs \\
\hline
\end{tabular}

Table 7: Details of Operating Cost

Source: Tariff Authority for Major Ports

\section{Tariff for Mobile Cranes}

\begin{tabular}{|l|l|l|}
\hline Si. No & Type of Cargo & Rate per Ton @ Rs. \\
\hline 1 & Dry Bulk & 50.0 \\
\hline 2 & Break Bulk (steel) & 40.0 \\
\hline 3 & Break Bulk (Others) & 120.0 \\
\hline
\end{tabular}

Table 8: Tariff Rate

Source: website Cochin Port Trust

The same HMC can be used for Dry Bulk and Break Bulk with different grabs Break bulk handled last year= 10.27 lakh ton=1. $027 \mathrm{MT}=1027000$ ton

Revenue from Cargo handling $=1027000 \times 120=12.32$ Crore per annum

Operating Cost of Crane $=6.78$ Crores per annum

Balance on hand $=5.54$ Crore per annum

Capital cost $=23.52$ crores

The expected period of Break Even at present condition= 4 years and 3 months 


\section{Reduction in Average turnaround time}

Present average turnaround time $=5.98$ days

Capacity of crane $=13209 \mathrm{~T} / \mathrm{hour}$

No of ship entered with dry bulk 2010-2011=59 no

Total ton of cargo handles in 2010-2011= 1027000 ton

No of days required for unloading ire cargo $=1027000 / 13209=77.75$ Days

Improved average turnaround time $=77.75 / 59=1.32$ Days

\subsection{DISCUSSION ON CHANGING BUSINESS ENVIRONMENT}

In the Changing business environment the organizations which need to survive in the industry should adopt any of the following strategies

* Expansion of Business

* Acquisition on new Companies

* Merging with other Companies

* Formation of Strategic Alliance

The opportunities Expansion of business and the formation of strategic alliances are two opportunities in front of the organization by taking the advantage following.

Formation of strategic alliance with the Cochin Shipyard they are expert in shipbuilding and ship maintenance located only $5 \mathrm{Km}$ away from the port premises. The other opportunity in front of the Port trust is that Cabotage rule is relaxed for the ICTT Vallarpadam it provides a huge opportunity for the Cochin Port in the area of expansion of their business in ship repairing. The proposed Vihinjam Port also brings the same opportunity for the port trust.

This study identifies the absence of quality circle in all the areas of the port operation, which can be seen from the present organizational structure of the Cochin Port trust shown in the following Fig 6.1. The head of the department of the organization will not get sufficient time to ensure the quality and effective operation of the organization, also due to the reason that the Chairman and Deputy Chairman are nominated members by the Central government it also brings the issue that the nominated persons may not be experienced person in port operation and port business, most of the cases his core competency will be limited only in administrative activities

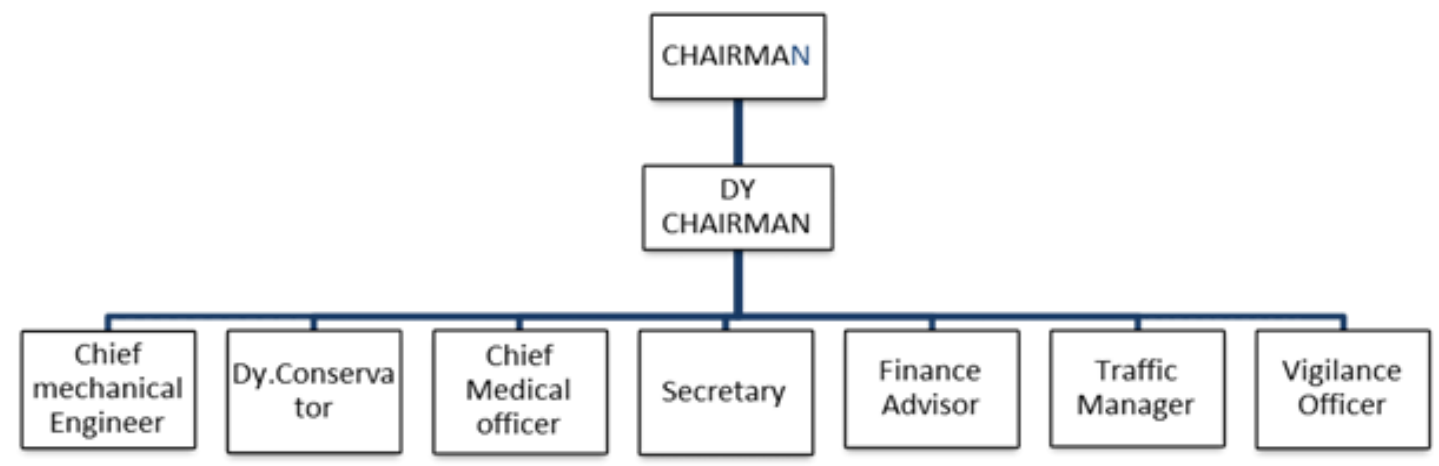

Fig 19: Present organizational structure of Cochin port Trust 
The inefficiency in the structure of the organization created following problems

$>$ Cochin port Trust could not collect single money from the 11th five year plan by submitting a valid project report.

$>$ Lack of coordination in Mechanical, Marine, Traffic department created an increased pre berthing detention time, turn round time. Poor financial performance, Poor capacity utilization.

$>$ The management of Cochin port trust could not identify the crises in a financial situation that they are going to face.

$>$ For any organization want to sustain in this type of business environment should possess a strong quality team inside the organization that was not present in the organization for the period of study.This created a pathetic financial situation that the port is facing now.

$>$ The Port Trust could not be able to create employment opportunity for the last 15 years. It is due to the poor utilization of natural resources by the management. It should be treated as the National waste.

$>$ No organization can be profitable with unsatisfied employees and bad working culture. The survey conducted among the skilled workers as the part of this study identifies this pathetic situation.

\subsection{PROPOSED ORGANIZATIONAL STRUCTURE}

Cochin Port Trust can take the advantage of these opportunities only by creating a technical governing body followed by a quality circle in all the departments as shown if Fig.

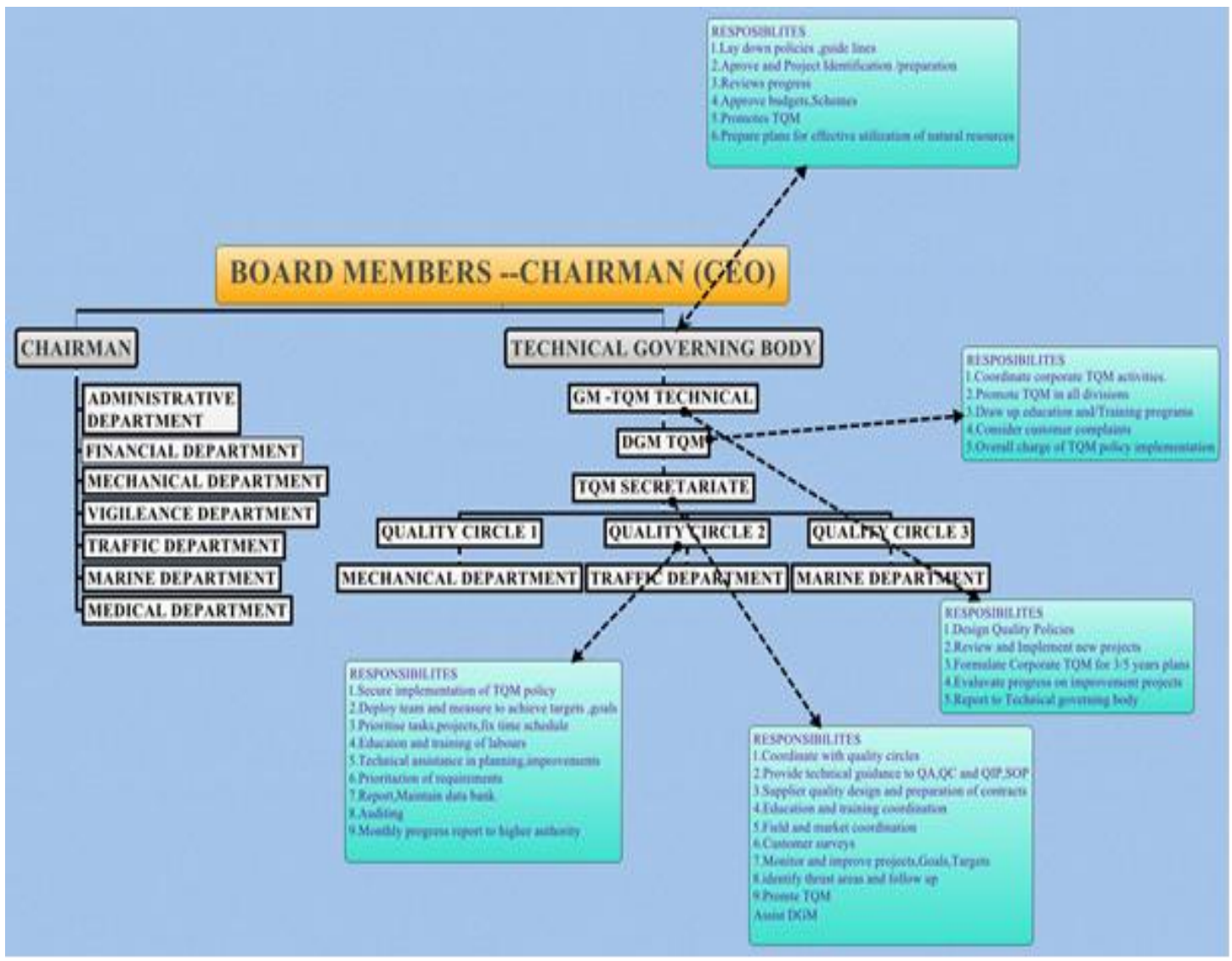

Figure 20: Proposed organizational structure of Cochin port Trust 


\subsection{CONCLUSION}

India's rise in recent years is a most prominent development in the world economy. India has re-emerged as one of the fastest growing economies in the world. India could unleash its full potential, provided it improves the infrastructure facilities, which are at present not sufficient to meet the growing demand of the economy. Failing to improve the country's infrastructure will slow down India's growth process. Therefore, Indian government's first priority is rising to the challenge of maintaining and managing high growth through investment in infrastructure sector like Ports, Electricity, Roads and Bridges, Airports. It is generally estimated that the lack of infrastructure is one of the major constraints on India's ability to sustain a high rate of growth in India's GDP.

The recent accelerated growth in Indian economy and trade underscores the increasing criticality of the shipping sector in India, as the bulk of the countries Export-Import trade takes place through the maritime route. Almost $95 \%$ by volume and $70 \%$ by value of India's global merchandise trade is carried through the sea route [2].

The case studies on Cochin port trust suggest a change in organizational structure for making this organization capability to provide a support to the country for its future expectations regarding the economic growth.

The study also reveals a situation that insufficient material handling equipment in port operation is the major factor for current port performance. The study also suggests and hope that modification proposed in the organizational structure will find new opportunities for port trust and will submit new project report in front of the government.

A detailed study should be conducted on our 12 major ports to enhance the capacity utilization. Improvement of human resource productivity through enhanced training and redeployment of surplus human resources is a major area to be addressed. Equally important, ports would need to pay greater attention to selection, deployment, and operation as well as maintenance of the cargo handling equipment.

[1] CPT Administrative Reports 2005-11

\section{References}

[2] Eleventh Five Year Plan Volume III Planning Commission Government of India

[3] Web site Cochin Port trust

[4] Text Book: Total Quality Management by S.M Sundara Raju,

[5] Text Book: Research Methodology by Paneer Selvam

\section{AUTHOR BIOGRAPHY}

Muhammed Salih.K, Post Graduate student ,Department of Mechanical Engineering, Mar Athanasius College of Engineering, Kothamangalam,Kerala,India.

Dr. Binu C Yeldhose, Professor, Department of Mechanical Engineering, Mar Athanasius College of Engineering, Kothamangalam, Kerala, India. 